Scientific Review - Engineering and Environmental Sciences (2021), 30 (1), 117-133

Sci. Rev. Eng. Env. Sci. (2021), 30 (1)

Przegląd Naukowy - Inżynieria i Kształtowanie Środowiska (2021), 30 (1), 117-133

Prz. Nauk. Inż. Kszt. Środ. (2021), 30 (1)

http://iks.pn.sggw.pl

DOI 10.22630/PNIKS.2021.30.1.11

Pham Thi Hai HA, Nguyen Thi HOA, Pham Tien BINH

National University of Civil Engineering, Faculty of Architecture and Planning

\title{
Simple method to improve the TCXDVN 306:2004 indoor climate standard for closed office workplaces in Vietnam
}

Key words: thermal comfort, artificial indoor environment, standard indoor climatic parameters, office workplaces, energy efficient building, Vietnam

\section{Introduction}

People spend $86.9 \%$ of the day living, working, and relaxing in indoor environments (Klepeis et al., 2001). Accordingly, indoor thermal comfort is regarded as one of the most significant factors affecting environmental satisfaction (Nasrollahi, Knight \& Jones, 2008). Undesirable thermal conditions can lead to occupant dissatisfaction which, in turn, has an adverse effect on their productivity, performance (Budaiwi, 2006). Thermal comfort is also critical to planning for energy efficient building design and overall post-occupancy evaluations.

The ANSI/ASHRAE 55-2017 standard defines the term thermal comfort as the condition of mind that expresses satisfaction with the thermal environment and is assessed by subjective evaluation
(American National Standards Institute/ /American Society of Heating, Refrigerating and Air-Conditioning Engineers [ANSI/ASHRAE], 2017). The factors affecting thermal comfort is normally dependent on four environmental parameters (dry bulb temperature, air humidity, air velocity and mean-radiant temperature) and two personal (clothing-insulation and physical activity) parameters (Szokolay, 2004). In office buildings, indoor temperature is one of the main influencing factors: direct (when thermal comfort is not obtained) as well as indirect (when sick building syndrome symptoms occur).

\section{Overview of common assessment measures for thermal comfort worldwide}

Initially, the definition of thermal comfort stems from effective temperature (ET), proposed by Houghten and Yagloi (1923). The effective temperature inte- 
grates air temperature, air humidity, and wind velocity into one unique environmental indicator. In 1932, the ASHRAE published a nomogram representing the index of effective temperature $(E T)$. They used the ET, which would be used extensively over the next 50 years.

From the early 1960s there were many researchers working in the field of thermal comfort. The best-known and most influential theory was Fanger's new model (1970). It is the model of thermal comfort - the predicted mean vote $(P M V)$, focusing on the relationship between the physical parameters of the environment, the physiological parameters of people and the perception of comfort expressed by people themselves. The $P M V$ indicator predicts the level of thermal comfort on a seven-grade sensation scale $(-3$ : cold, -2 : cool, -1 : slightly cool, 0 : neutral, +1 : slightly warm, +2 : warm, +3 : hot). As a follow-up to the $P M V$ index, Fanger introduced the index of predicted percentage of dissatisfied $(P P D)$, includ- ing the human factor, showing the majority percentage of respondents who feel either satisfied or unsatisfied with their working or living environment (Fig. 1). This $P M V$ is used in the ISO 7730-2005 (International Organization for Standardization [ISO], 2005) and the ANSI/ /ASHRAE 55-2017 standard. This model is often applied to buildings using air conditioning systems when building occupants are allowed to adjust the indoor environmental conditions to the desired level of thermal balance.

During the 1980s, Michael Humphreys initiated discussion about adaptive principles related to thermal comfort. De Dear, Brager and Cooper (1997) developed an adaptive model of thermal comfort: they predicted the temperature of comfort based on new findings of self-regulation of human bodies and applied that to naturally ventilated buildings. This research was subsequently included in both the ANSI/ASHRAE 55-2017 and the BS EN 16798-1:2019 standard (Brit-

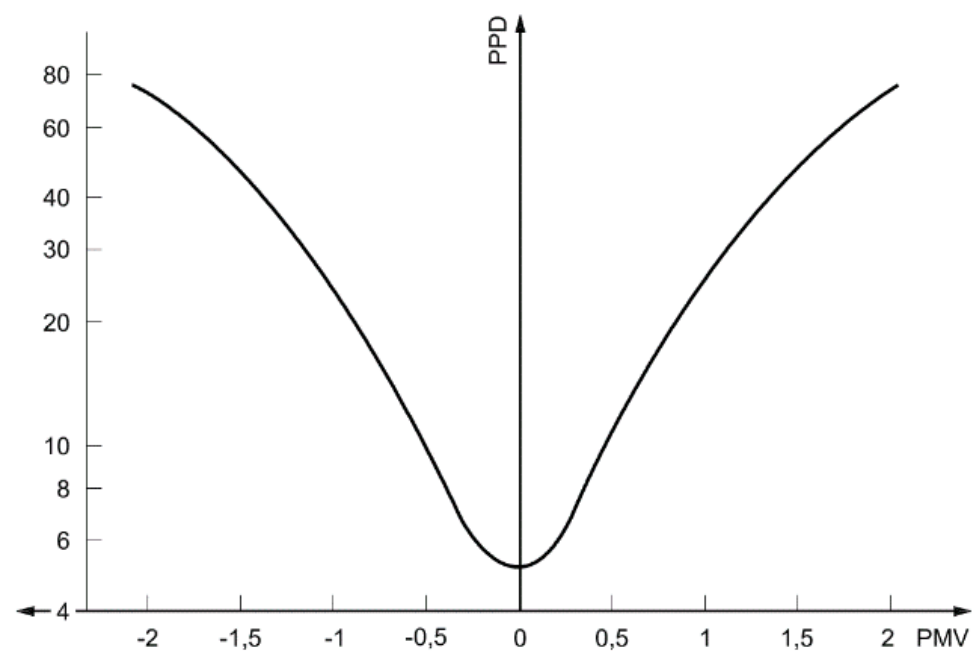

FIGURE 1. The predicted percentage of dissatisfied index $(P P D)$ as function of the predicted mean vote index $(P M V)$ 
ish Standards Institution [BSI], 2019). De Dear and Brager (2002) discussed the process of publishing a new adaptive comfort standard incorporated into the ANSI/ASHRAE 55-2017 standard that allows warmer indoor temperatures for naturally ventilated buildings during summer and in warmer climate zones.

Various field studies on the concept of thermal comfort have been carried out on office buildings with ducted air-conditioning systems by different objectives, methods, and in different climate zone in recent years. Bakhtiari, Akander and Cehlin (2020) study on thermal comfort by on-site measurements, BMS data logging and standardized questionnaire in the historic City Hall of Gävle, Sweden. Szabo and Kajtar (2018) carried on-site measurements in office buildings with different air-conditioning systems during the summer season for thermal comfort analysis, using $P M V, P P D$ model and the local discomfort based on draught rate $(D R)$. De Vecchi, Candido, de Dear and Lamberts (2017) carried the indoor climatic field studies by measurements and online questionnaires in three office buildings with two different environmental control strategies (two with mixed-mode ventilation and one with permanent air-conditioning). The results obtained in this study are used as a baseline for a Brazilian thermal comfort standard. Simons, Koranteng, Adinyira and Ayarkwa (2014) used quantitative survey along with questionnaires to assess the thermal comfort in multi storey (naturally and mechanically ventilated) office buildings in Accra, Ghana, using the $P M V$ and the $P P D$ models. Tao, Li, Qiu and Zhang (2014) studied the indoor air environmental conditions of three different typical office buildings in Xi'an (China) by actual measurement and questionnaire survey. This study noticed that there was a remarkable difference between the $P M V$ index and actual-measurement thermal sensation vote (TSV) in evaluating indoor thermal environments in typical office buildings.

\section{Overview of studies on thermal comfort for Vietnamese people}

In the 1960s and 1980s, many scientists in Vietnam conducted research projects on human thermal comfort in houses and low-rise office buildings. Tables 1 and 2 summarize the results.

Dung (1995) in research of human thermal comfort in Vietnam found that the relationship between temperature and humidity greatly impacts human comfort under hot and humid climate conditions. Nguyen (2002) carried out several tests regarding thermal comfort on some students in Hanoi and Vinh city. However, his research outcomes were just about an assessment of an expansion of the thermal comfort zone, especially towards higher air humidity and wind velocity. The research results published by Nguyen, Singh and Reiter (2013) showed a neutral level of temperature in ASEAN countries would be $27.1^{\circ} \mathrm{C}$ for a naturally ventilated room and $25.9^{\circ} \mathrm{C}$ for an air-conditioned room, these values approximate those shown in Table 2 . In recent years, there were some studies on micro-climate conditions in educational and residential buildings in Ho Chi Minh City and Da Nang and in few office buildings in Hanoi (e.g. Huong, 2001; Khanh, 2011; Nguyen, Singh 
TABLE 1. Effective temperature-based limit indicators of thermal comfort in research projects in Vietnam from the 1960 s to 1980 s

\begin{tabular}{|c|c|c|c|c|c|c|c|c|}
\hline \multirow{3}{*}{ Researcher } & \multirow{3}{*}{ Season } & \multirow[b]{2}{*}{ Cold } & \multirow[b]{2}{*}{$\begin{array}{l}\text { Slightly } \\
\text { cold }\end{array}$} & \multicolumn{3}{|c|}{ Comfortable } & \multirow[b]{2}{*}{$\begin{array}{l}\text { Slightly } \\
\text { hot }\end{array}$} & \multirow[b]{2}{*}{ Hot } \\
\hline & & & & $\begin{array}{l}\text { lower } \\
\text { limit }\end{array}$ & $\begin{array}{l}\text { com- } \\
\text { pletely } \\
\text { comfort- } \\
\text { able }\end{array}$ & $\begin{array}{l}\text { upper } \\
\text { limit }\end{array}$ & & \\
\hline & & \multicolumn{7}{|c|}{${ }^{\circ} \mathrm{C}$} \\
\hline \multirow{2}{*}{ Dang (1981)* } & summer & - & - & - & 24.4 & 27.0 & 28.5 & $\geq 29.2$ \\
\hline & winter & $\leq 17.3$ & 18.5 & 20.0 & 23.3 & 26.5 & - & - \\
\hline \multirow{2}{*}{ Con (1985) } & summer & - & - & 18.8 & 23.0 & 27.0 & - & - \\
\hline & winter & - & - & 16.7 & 21.0 & 24.7 & - & - \\
\hline Anh (1984) & - & - & - & 20.0 & 23.7 & 27.5 & - & - \\
\hline
\end{tabular}

*The ET values investigated by Dang (1981) can be determined by means of ET nomogram of the American Society of Heating and Ventilating Engineers (ASHVE).

TABLE 2. Limit values of thermal comfort subject to air temperature in studies in Vietnam from the 1960 s to the 1980 s

\begin{tabular}{|c|c|c|c|c|c|c|}
\hline \multirow[b]{2}{*}{ Researcher } & \multirow[b]{2}{*}{ Season } & \multicolumn{3}{|c|}{ Air temperature $\left[{ }^{\circ} \mathrm{C}\right]$} & \multirow[b]{2}{*}{$\begin{array}{l}\text { Air humid- } \\
\text { ity }[\%]\end{array}$} & \multirow[b]{2}{*}{$\begin{array}{c}\text { Wind } \\
\text { velocity } \\
{\left[\mathrm{m} \cdot \mathrm{s}^{-1}\right]}\end{array}$} \\
\hline & & $\begin{array}{l}\text { lower limit } \\
\text { of comfort }\end{array}$ & $\begin{array}{l}\text { completely } \\
\text { comfort- } \\
\text { able }\end{array}$ & $\begin{array}{l}\text { upper level } \\
\text { of comfort }\end{array}$ & & \\
\hline \multirow{2}{*}{ Dang (1981) } & summer & - & 25.5 & 29.5 & 80 & \multirow{2}{*}{$0.3-0.5$} \\
\hline & winter & 21.5 & 24.5 & 29.0 & 80 & \\
\hline Thiem (1984) & - & 23.0 & $24.0-25.0$ & $26.0-27.0$ & $60-80$ & 0.1 \\
\hline $\begin{array}{l}\text { Phong, Uyen, Lanh } \\
\text { \& Anh (1984) }\end{array}$ & - & - & - & 28.9 & 84 & - \\
\hline
\end{tabular}

\& Reiter, 2012; Tuan \& Le, 2015; Tuan, Dung \& Vinh, 2016; Nguyen \& Tran, 2017). Dung and Kien (2019) provides an overview of situation of energy consumption and indoor conditions of office buildings in major cities of Vietnam, and gives some ideas for improving the energy efficiency and indoor comfort of office buildings.

In Vietnam, there has been so far only one standard - the TCXDVN 306:2004, which determines standard micro-climatic specifications applicable to office workplaces (Ministry of Con- struction of Vietnam, 2004). Nevertheless, in fact, this standard is rarely used, because of the following shortcomings and disadvantages:

- It specifies the standard values for micro-climate parameters on the basis of the "Scale of thermal comfort for Vietnamese people" proposed by Dang (1981) (as presented in Tables 1 and 2). That comes from an experimental study on 1,100 participants conducted by Dang (1981) in 1966-1967 . This scale of thermal comfort corresponds to the $50 \%$ probability 
of the total number of participants in the $P M V$ experiment regarding their thermal comfort, while according to the requirement of the ISO 7730-2005, the ANSI/ASHRAE 55-2017, the standard micro-climate parameters are divided into three categories: Category A $(P M V=90 \%)$, Category $\mathrm{B}(P M V=80 \%)$, and Category C $(P M V=70 \%)$.

- It does not specify clearly what kind of indoor environment it should be: natural or artificial;

- It was formulated primarity in reference to Russian standard the GOST 30494-1996 (Standartinform, 1996), while the climate conditions in Russia are very different from those in Vietnam.

Most of the office buildings in Vietnam today are equipped with air-conditioning systems, either local or central systems with various design and installation concepts. Technically, this is the best solution to control the indoor climate in office buildings in a hot and humid tropical country. For this reason, it is necessary to investigate the current situation of indoor climate conditions of workplaces in office buildings in all three regions of Vietnam: North, Central and South, so that the aforementioned Vietnamese standard can be properly adjusted to meet the real demand for thermal comfort as well as for energy efficiency required in a highly comfortable built environment.

\section{Material and methods}

In order to evaluate the current situation of indoor climate conditions and thermal comfort in closed office work- places, the two methods were used as follows: physical measurements and questionnaires survey. More specifically:

- Area of survey: Five office buildings, of which two buildings are located in Hanoi, one in Da Nang, and two in Ho Chi Minh City. The pictures and data for these five office buildings are shown in Table 3 (exemplary measuring points location in Fig. 2). In each office building, two rooms were selected, one on a middle floor and one on an upper floor, or two on the same floor but facing different directions.

- Time of surveys: In Hanoi, there are two distinct seasons (winter and summer) and the worst case time for surveying in Hanoi is during the hottest months of the year (July and August) as well as in the coldest months of the year (January and February). In Da Nang and Ho Chi Minh City, it is warm throughout the year, therefore the time for surveying should also be in July for Da Nang and in April for Ho Chi Minh City. Each office building was measured within one day, during five time intervals: $8: 00$ $-8: 30, \quad 10: 00-10: 30,12: 00-12: 30$, 14:00-14:30, 16:00-16:30.

- One paper questionnaire had been prepared beforehand to evaluate the quality of indoor climate subject to the individual feelings of the occupants working in a room selected for survey.

- Measurement data: Indoor climate conditions, including air temperature $-T_{\text {in }}\left[{ }^{\circ} \mathrm{C}\right]$, indoor air humidity $-\varphi_{\text {in }}$ $[\%]$, indoor air velocity $-v_{\text {in }}\left[\mathrm{m} \cdot \mathrm{s}^{-1}\right]$ and mean-radiant room surface temperatures $-T R\left[{ }^{\circ} \mathrm{C}\right]$; outdoor weather 


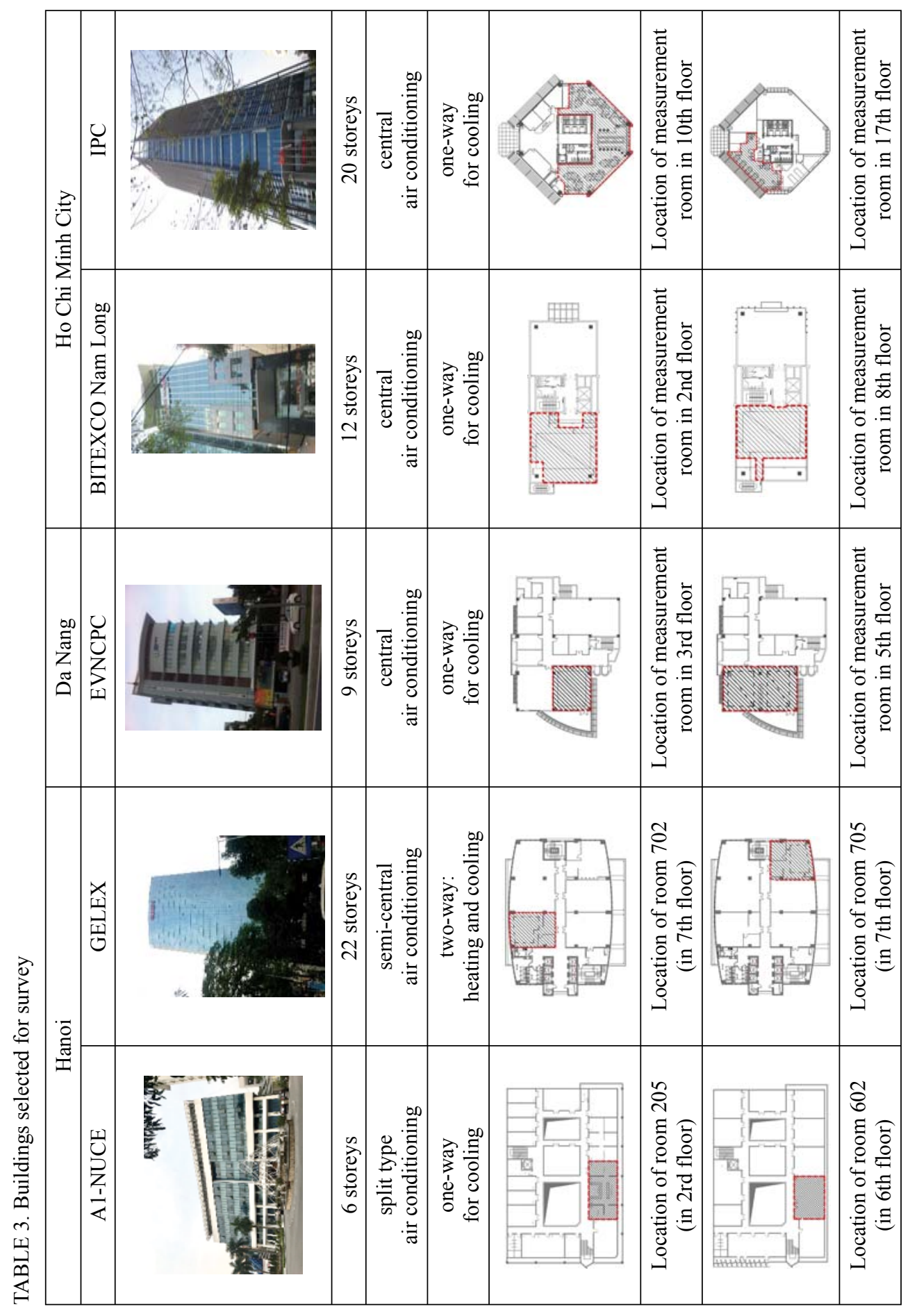




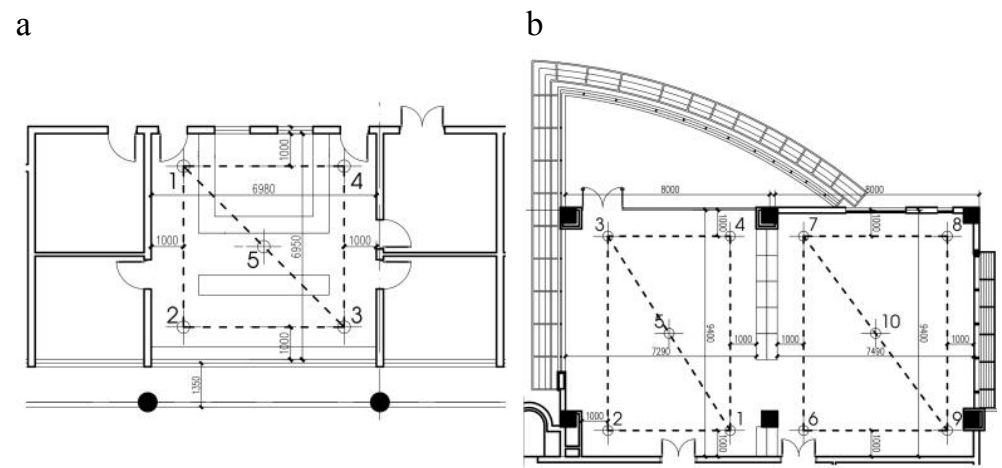

FIGURE 2. Location of measuring points in: a - room 205 of A1-NUCE building; $b$ - room of 5th floor of EVNCPC building

conditions, including air temperature $-T_{\text {out }}\left[{ }^{\circ} \mathrm{C}\right]$, air humidity $-\varphi_{\text {out }}\left[{ }^{\circ} \mathrm{C}\right]$ and air velocity $-v_{\text {out }}\left[\mathrm{m} \cdot \mathrm{s}^{-1}\right]$. The measurements of indoor and outdoor climate conditions were taken in accordance with the TCXDVN 306:2004 standard.

- Measurement positions: The following parameters $T_{i n}, \varphi_{i n}, v_{i n}$ were measured at least five points evenly distributed in the room workplaces, at the level of $1.2 \mathrm{~m}$ from the floor; parameter $T R$ was measured at the middle point of the room. Outdoor weather conditions were measured one point only, representing the surrounding area of the building, also at $1.5 \mathrm{~m}$ level from the ground.

In order to assess thermal comfort, the $E T$ and the $P M V$ indicators were used. The ASHRAE ET nomogram was used to calculate the ET indicators. A program called CBE Thermal Comfort Tool (Tartarini, Schiavon, Cheung \& Hoyt, 2020), was used to calculate the $P M V$ indicators.

\section{Results and discussion}

\section{Outdoor and indoor climate conditions}

In Hanoi, two surveys were conducted in winter of 2018: on January 18th (A1 Building at the NUCE) and on February 5th (GELEX Building) and two surveys were conducted in summer of 2018: on August 21st (A1 Building at the NUCE) and on July 5th (GELEX Building) during working hours (from 8 am to $5 \mathrm{pm}$ ).

In Da Nang, a survey was conducted on July 27th 2018 during working hours in EVNCPC Building.

In Ho Chi Minh City, two surveys were conducted in 2018: on April 12th (Bitexco Nam Long Building) and on April 13th (IPC Building) during working hours.

Tables 4, 5 and 6 illustrate the results of outdoor and indoor climate conditions (air temperature, air humidity and air velocity) during working hours in measuring days in Hanoi, Danang and 


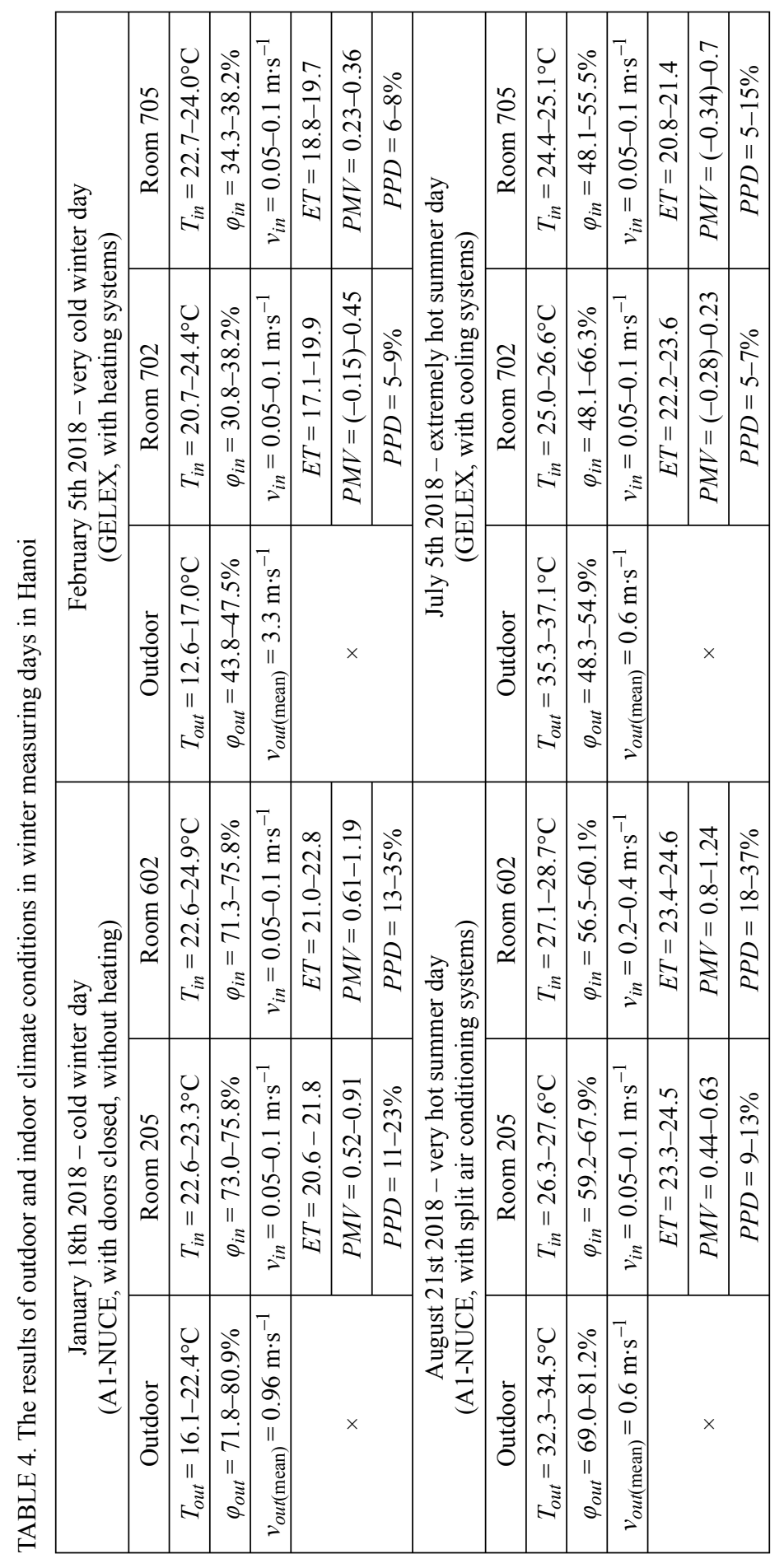


TABLE 5. The results of outdoor and indoor climate conditions in measuring day in Da Nang

\begin{tabular}{|c|c|c|}
\hline \multicolumn{3}{|c|}{$\begin{array}{c}\text { July 27th 2018 - hot day } \\
\text { (EVNCPC, with cooling systems })\end{array}$} \\
\hline Outdoor & Room of 3rd floor & Room of 5th floor \\
\hline$T_{\text {out }}=28.0-29.8^{\circ} \mathrm{C}$ & $T_{\text {in }}=26.6-27.1^{\circ} \mathrm{C}$ & $T_{\text {in }}=25.5-26.4^{\circ} \mathrm{C}$ \\
\hline$\varphi_{\text {out }}=69.5-80.7 \%$ & $\varphi_{\text {in }}=59.5-63.8 \%$ & $\varphi_{\text {in }}=53.5-60.5 \%$ \\
\hline$v_{\text {out }(\text { mean })}=0.3 \mathrm{~m} \cdot \mathrm{s}^{-1}$ & $v_{\text {in }}=0.05-0.1 \mathrm{~m} \cdot \mathrm{s}^{-1}$ & $v_{\text {in }}=0.05-0.1 \mathrm{~m} \cdot \mathrm{s}^{-1}$ \\
\hline & $E T=23.5-24.1$ & $E T=22.1-23.1$ \\
\cline { 2 - 3 }$\times$ & $P M V=0.66-0.76$ & $P M V=0.08-0.58$ \\
\cline { 2 - 3 } & $P P D=14-17 \%$ & $P P D=5-12 \%$ \\
\hline
\end{tabular}

Ho Chi Minh City. These micro-climatic survey measurement results have been transformed into $E T$ values and $P M V$, $P P D$ indicators. Because the office occupants all use computers at work, the research team estimated human metabolic heat to be 1.1 met (typing) as specified in the BS EN 16798-1:2019 and the ANSI/ASHRAE 55-2017 standard while calculating $P M V$ and $P P D$ indicators. Clothes heat resistance would be 0.5 clo during summer, and 1.0 clo during winter, in office rooms with heating systems (GELEX Building), and 1.2 clo in office rooms without heating systems (A1 Building at the NUCE).

The number of questionnaires collected corresponded with the number of officers/staffs working in those office workplaces on their respective survey days. One hundred thirty-two questionnaires were collected. Figure 5 compares results of thermal comfort subject to temperature expressed by the staffs in measured office workplaces during winter and summer times. With regard to air humidity: in office rooms with relative humidity lower than $60 \%: 87.2 \%$ of the staff said that air humidity was at a moderate level, $12.8 \%$ felt too dry. In rooms with relative humidity between 60 and $75 \%$ :
$85 \%$ of the staff said that air humidity was at a moderate level while $15 \%$ felt too dry. Also with regard to wind velocity: $72.6 \%$ said that wind velocity was at a moderate level; $25 \%$ said that it lacked air movement, while $2.4 \%$ felt that it was windy.

The study results showed that:

- Average relative humidity in office workplaces in buildings with air conditioning systems varied between 46 and $64 \%$. Air velocity distributed within $0.05-0.2 \mathrm{~m} \cdot \mathrm{s}^{-1}$ (most cases approximately $0.1 \mathrm{~m} \cdot \mathrm{s}^{-1}$ ), this value is similar to the average air velocity $\left(0.04 \mathrm{~m} \cdot \mathrm{s}^{-1}\right)$ of the indoor thermal environments survey in three office buildings in the city of Xi'an (Tao et al., 2014). In the meantime, the TCXDVN 306:2004 standard requires that wind velocity should be $0.3-0.5 \mathrm{~m} \cdot \mathrm{s}^{-1}$ for $80 \%$ humidity. Thus, humidity and wind velocity values in the mentioned standard should not apply to air-conditioned buildings.

- Due to adaptation to very humid environment in hot and humid tropical climates, $85 \%$ of the staff in rooms with air humidity between 60 and $75 \%$ felt comfortable with this hu- 


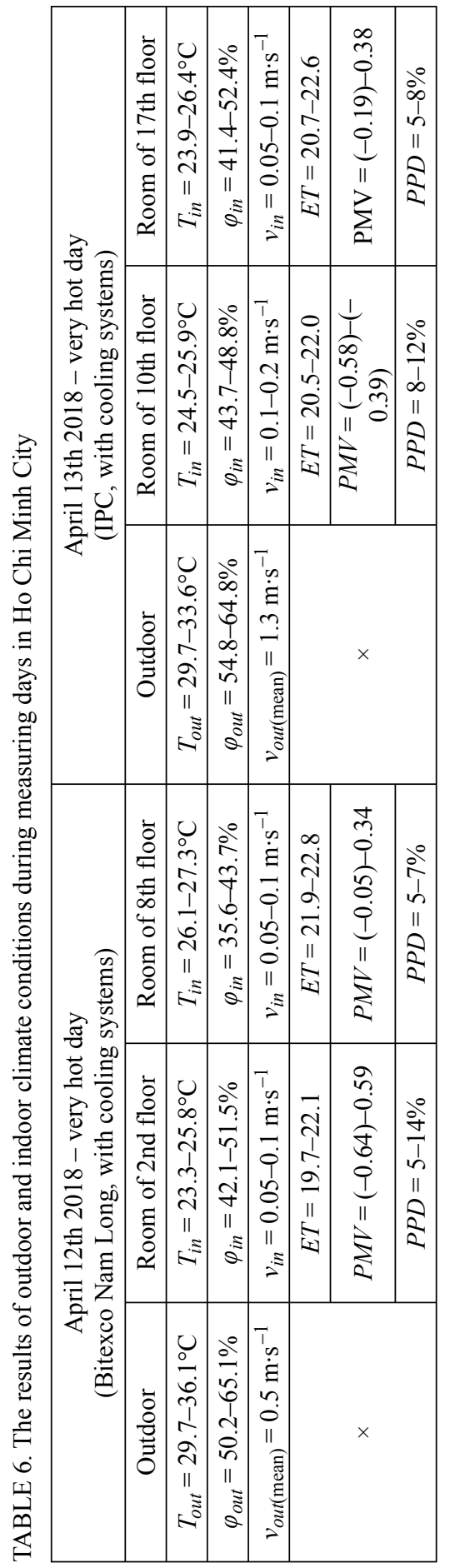

midity, while $60 \%$ air humidity is the upper limit of the ASHRAE comfort zone.

- The assessment results based on ET and $P M V$ indicators in A1 Building at the NUCE (without heating) on January 18th 2018 (cold winter day) brought thermal comfort to building occupants. The opinion survey revealed that most of the staff felt comfortable, in accordance with the $E T$ and $P M V$-based evaluation.

- The assessment results based on the $E T$ indicator in GELEX Building (with heating) on February 5th 2018 (very cold winter day) exceeded the comfort zone for winter time (slightly cold). Nevertheless, the assessment results based on $P M V$ indicator stayed entirely within comfort zone, also in accordance with the opinion survey results of building occupants. It is possible to see that ET-based thermal comfort in the TCXDVN 306:2004 standard does not always correspond well to perceived (surveyed) thermal comfort.

- Average daily ET values during summer time in office rooms varied between $20.5^{\circ} \mathrm{C}$ and $23.8^{\circ} \mathrm{C}$. These values are lower than $E T$ value for completely comfortable $24.4^{\circ} \mathrm{C}$ in summer months with reference to the mentioned standard.

- Results of the $P M V$-based assessment during summer months indicated that except room 602 with average daily $P M V=1.16$, beyond comfort zone (rather warm), in remaining rooms the $P M V$-based values all fell within the comfort zone. However, the opinion survey undertaken by staff working in room 602 


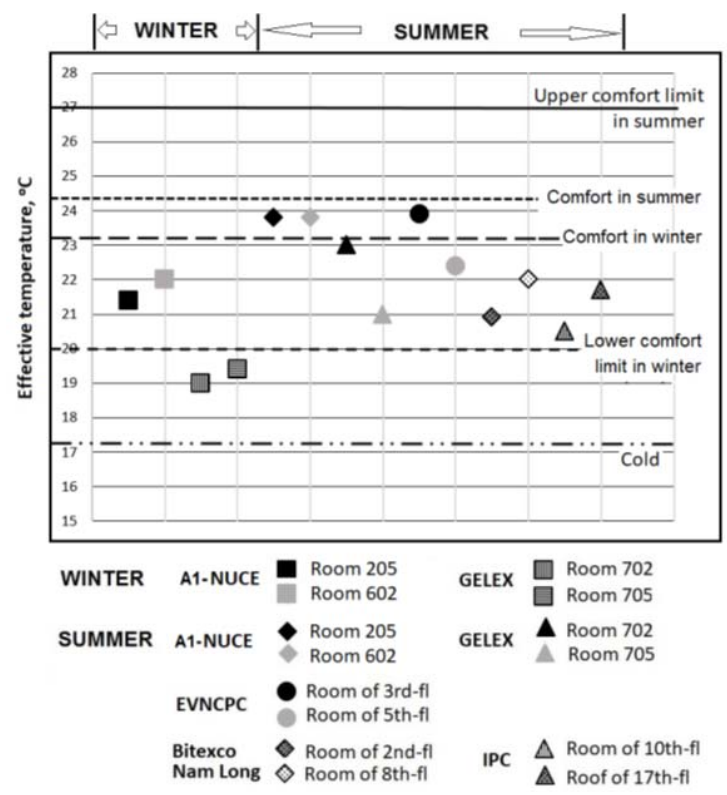

FIGURE 3. Average daily effective temperature value in surveyed rooms in five office buildings (in winter and summer)

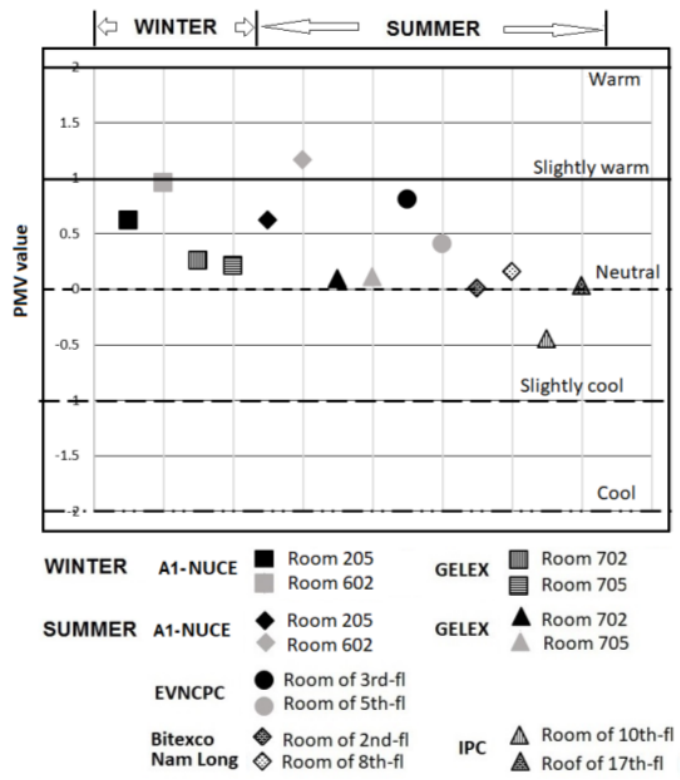

FIGURE 4. Average daily predicted mean vote value in surveyed rooms in five office buildings (in winter and summer) 


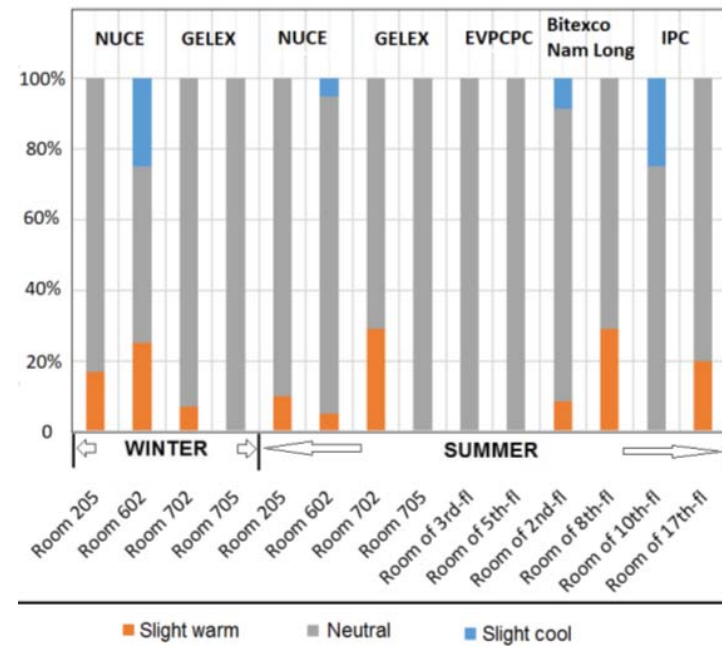

FIGURE 5. Interview results of thermal comfort subject to temperature among the staff working in office rooms measured in winter and summer time

revealed that more than $90 \%$ of occupants felt comfortable. Therefore, $E T$ thermal comfort during summer time following mentioned standard would be more appropriate for thermal comfort among Vietnamese people than a thermal comfort scale based on $P M V$ indicators.

- Although these investigations did not have sufficient samples to establish the confidence level as expected, the survey and measurement results also demonstrate that some micro-climatic parameters in mentioned standard should be adjusted and updated for current use.

\section{Recommendations to update current standards in micro-climate}

The TCXDVN 306:2004 specifies standard values of micro-climate on the basis of "Scale of thermal comfort for Vietnamese people" as proposed by Dang (1981). The curve in Figure 6 represents the relationship between the level of thermal comfort (\% probability of thermal comfort) for Vietnamese people based on experiments by Dang (1981). The authors add three thermal comfort zones A, B and C to "Scale of thermal comfort for Vietnamese people". This graph considers metabolic heat of a healthy person (reading books, doing office paperwork, undertaking research, etc.) is 1.1 met, and heat resistance for normal clothes is $0.4-0.5$ clo during summer, and 0.9-1.0 clo during winter.

Comment on Figure 6: If we extend the winter comfort curve and summer comfort curves in Figure 6 and compare this graph to the curve representing the relationship between $P P D$ and $P M V$ sensation scale, following theoretical calculations in the ISO 7730-2005 standard from Figure 1, it is possible to see that the two curves are exponentials and quite similar in variability. There is only one difference: one is convex while the other is concave. The reason is given as follows: $P P D$ is measured in \% according to the 


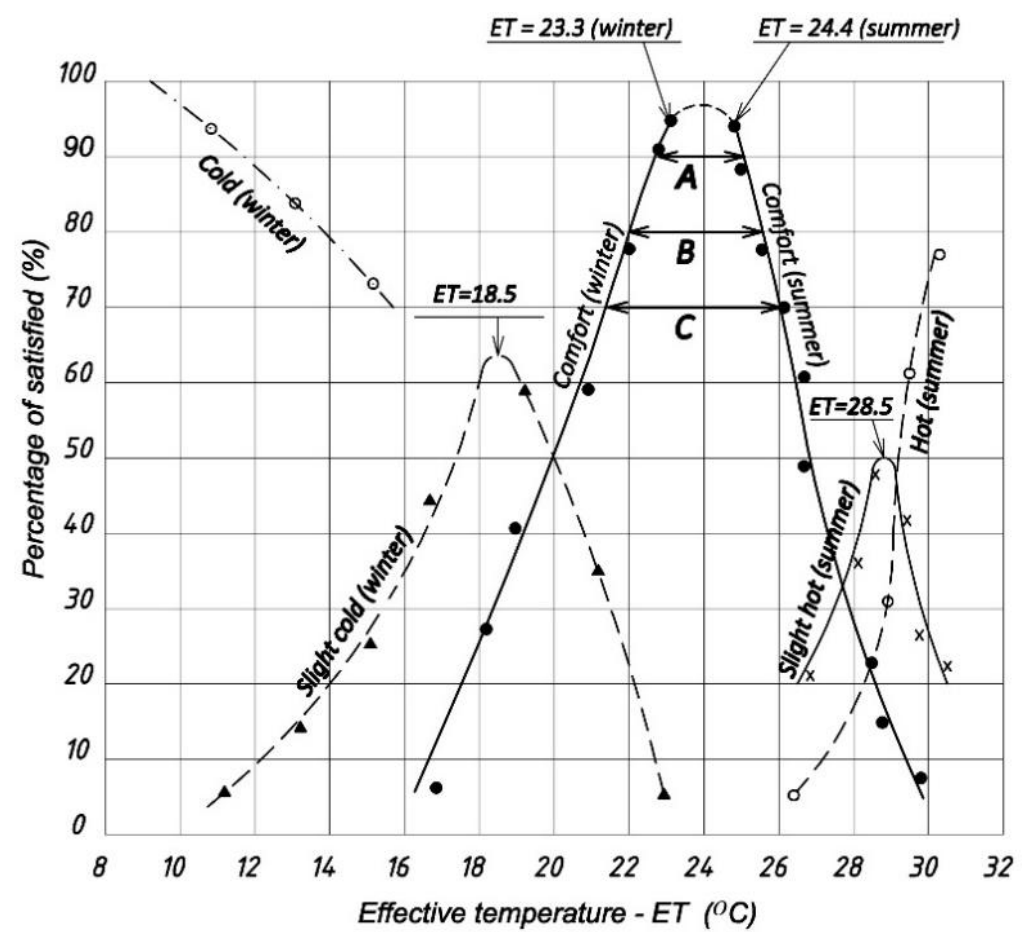

FIGURE 6. Relationship between effective temperature and probability of feeling hot or cold by Vietnamese people (Note: Thermal comfort zones A, B, C have been added)

ISO 7730-2005 standard, and the graph proposed by Dang (1981) uses $P M V$ unit [\%], whereas $P P D[\%]=100 \%-P M V$ $[\%]$. Thus, the graph showing the relationship between $E T$ and probability of feeling hot or cold by Vietnamese people proposed by Dang (1981) can be used as a foundation reference to establish the limits of micro-climatic comfort and modify the TCXDVN 306:2004 standard wherever possible, as more comprehensive experimental studies on thermal comfort of Vietnamese people are not available.

As required by the ISO 7730-2005, the ANSI/ASHRAE 55-2017, the BS EN 16798-1:2019 and the GOST 30494-1996 standard, the limits of thermal comfort to be included in building micro-climatic regulations depend on the function of the building and should be divided in three categories $\mathrm{A}, \mathrm{B}$ and $\mathrm{C}$, corresponding to three levels of comfort: 90,80 and $70 \%$.

The research team analysed the experimental outcomes by Dang (1981) in the graphic "Relationship between $E T$ and probability of feeling hot or cold by Vietnamese people" in Figure 6 by means of the ISO 7730 method in order to differentiate the levels of thermal comfort on the basis of probability of thermal comfort in categories A, B, C (90, 80 and $70 \%$, respectively). It aims to standardize micro-climatic conditions in consideration of different levels of quality and comfort. The results are presented in Table 7. 
TABLE 7. Limits of thermal comfort for Vietnamese people on the basis of effective temperature (ET) and combination of parameters of air temperature $(T)$, humidity $(\varphi)$ and wind velocity $(v)$ for air-conditioned office rooms

\begin{tabular}{|l|c|c|c|c|}
\hline $\begin{array}{l}\text { Level of thermal } \\
\text { comfort } \\
- \text { Probability of } \\
\text { thermal comfort }\end{array}$ & $E T\left[{ }^{\circ} \mathrm{C}\right]$ & $\begin{array}{c}T\left[{ }^{\circ} \mathrm{C}\right] \\
(\varphi=60 \%, \\
\left.v=0.05-0.2 \mathrm{~m} \cdot \mathrm{s}^{-1}\right)\end{array}$ & $\begin{array}{c}T\left[{ }^{\circ} \mathrm{C}\right] \\
(\varphi=65 \%, \\
\left.v=0.05-0.2 \mathrm{~m} \cdot \mathrm{s}^{-1}\right)\end{array}$ & $\begin{array}{c}T\left[{ }^{\circ} \mathrm{C}\right] \\
(\varphi=70 \%, \\
\left.v=0.05-0.2 \mathrm{~m} \cdot \mathrm{s}^{-1}\right)\end{array}$ \\
\hline Comfort at 97\% & 23.8 & 27.1 & 26.7 & 26.3 \\
\hline Grade A, 90\% & $22.6-25.0$ & $25.8-28.4$ & $25.4-28.0$ & $25.0-27.6$ \\
\hline Grade B, 80\% & $22.0-25.5$ & $25.2-29.0$ & $24.8-28.5$ & $24.4-28.1$ \\
\hline Grade $\mathrm{C}, 70 \%$ & $21.5-26.0$ & $24.7-29.5$ & $24.3-29.0$ & $23.9-28.6$ \\
\hline
\end{tabular}

\section{Conclusions}

This research paper reports physical measurements and opinion surveys of current indoor climatic conditions in office workplaces for five representative office buildings in three cities, representing three climate zones in Vietnam: Hanoi, Da Nang and Ho Chi Minh City. Based on the survey and measurement results, and experimental results previously conducted by Dang (1981) the authors propose that the limits of thermal comfort for Vietnamese people should be established by using the classification of comfort of the ISO and the ASHRAE standard (in three levels of comfort: 90, 80 and $70 \%$ ), in order to standardize micro-climatic conditions in air-conditioned office buildings at different levels of comfort. In future, more experimental investigations into thermal comfort on a larger scale will help validate scales of thermal comfort appropriate for use throughout all climate zones in Vietnam.

\section{Acknowledgements}

This research is funded by National University of Civil Engineering (NUCE), Hanoi, Vietnam under grant
09-2019/KHXD-TĐ and by Ministry of Construction of Vietnam under grant MT 08-17. The authors are deeply thankful to Prof. Dr Pham Ngoc Dang and Dr Glenn Sweitzer for their support and advice.

\section{References}

American National Standards Institute/American Society of Heating, Refrigerating and Air-Conditioning Engineers [ANSI/ASHRAE] (2017). Thermal environmental conditions for human occupancy (ANSI/ASHRAE 55-2017). Atlanta: American Society of Heating, Refrigerating and Air-Conditioning Engineers.

Anh, N.H. (1984). Bioclimate diagram applied in the design of dwelling house. In Proceedings of Vietnam-Sweden Symposium: Vietnam Building Climatology. Hanoi (pp. B33-B41) [unpublished].

Bakhtiari, H., Akander, J. \& Cehlin, M. (2020). Evaluation of thermal comfort in a historic building refurbished to an office building with modernized HVAC systems. Advances in Building Energy Research, 14(2), 218-237. https://doi.org/10.1080/17512549.201 9.1604428

British Standards Institution [BSI] (2019). Energy performance of buildings. Part 1: Ventilation for buildings. Indoor environmental input parameters for design and assessment of energy performance of buildings addressing indoor 
air quality, thermal environment, lighting and acoustics. Module M1-6 (BS EN 16798-1:2019). London: British Standards Institution.

Budaiwi, I.M. (2006). An approach to investigate and remedy thermal-comfort problems in buildings. Building and Environment, 42(5), 2124-2131. https://doi.org/10.1016/ j.buildenv.2006.03.010

Con, N.H. (1985). Climatic, Architecture and Human. Hanoi: Science and Technology Publisher.

Dang, P.N. (1981). Climatic fundamentals of architectural design. Hanoi: Science and Technology Publisher.

De Vecchi, R.D., Candido, C., Dear, R. de, Lamberts, R. (2017). Thermal comfort in office buildings: Findings from a field study in mixed-mode and fully-air conditioning environments under humid subtropical conditions. Building and Environment, 123, 672-683. https://doi.org/10.1016/j.buildenv.2017.07.029

Dear, R.J. de \& Brager, G.S. (2002). Thermal comfort in naturally ventilated buildings: revisions to ASHRAE Standard 55. Energy and Buildings, 34(6), 549-561.

Dear, R. de, Brager, G. \& Cooper, D. (1997). Developing and adaptive model of thermal comfort and preference (final report ASHRAE RP-884). American Society of Heating, Refrigerating and Air Conditioning Engineers/Macquarie Research.

Dung, N.H. (1995). Discussions of human thermal comfort in Vietnam. In F. Nicol, M. Humphreys, O. Sykes, S. Roaf (eds.), Standards for Thermal Comfort: Indoor air temperatures for the 21st century (pp. 143-148). London: E \& FN Spon.

Dung, N.H.N. \& Kien, N.T. (2019). Recommendations for the design of an energy-efficient and indoor comfortable office building in Vietnam. In E. Motoasca, A. Agarwal, H. Breesch (eds.), Energy Sustainability in Built and Urban Environments. Energy, Environment, and Sustainability (pp. 67-90). Singapore: Springer. https://doi.org/10.1007/978-98113-3284-5_4

Fanger, P.O. (1970). Thermal comfort: analysis and applications in environmental engineering. Vanloese: Danish Technical Press.
Houghten, F.C. \& Yaglou, C.P. (1923). Determination of the comfort zone. Transactions of the American Society of Heating and Ventilating Engineers, 29, 165-176.

Huong, N.T. (2001). Report on research project "Initially assessing the factors which can cause the SBS disease in the offices in Vietnam and proposing solutions to improve the working environment". Hanoi [unpublished].

International Organization for Standardization [ISO] (2005). Ergonomics of the thermal environment. Analytical determination and interpretation of thermal comfort using calculation of the PMV and PPD indices and local thermal comfort criteria (ISO 7730-2005). Geneva: International Organization for Standardization.

Khanh, N.Q. (2011). Report on research project "Investigating and assessing the indoor environment quality of the working environment and the health of workers in office buildings. Proposing solutions" [unpublished].

Klepeis, N.E., Nelson, W.C., Ott, W.R., Robinson, J.P., Tsang, A.M., Switzer, P., Behar, J.V., Hern, S.C. \& Engelmann, W.H. (2001). The National Human Activity Pattern Survey (NHAPS): a resource for assessing exposure to environmental pollutants. Journal of Exposure Science and Environmental Epidemiology, 11(3), 231-252. https://doi. org/10.1038/sj.jea.7500165

Ministry of Construction of Vietnam (2004). Nhà và công trình công $c$ ng-Các thông $s$ vi khi h u tong phòng [Dwelling and public buildings - Parameters for micro-climates in the rooms] (TCXDVN 306:2004). Hanoi: Ministry of Construction of Vietnam [transl. from Vietnamese].

Nasrollahi, N., Knight, I. \& Jones, P. (2008). Workplace satisfaction and thermal comfort in air conditioned office buildings: Findings from a summer survey and field experiments in Iran. Indoor and Built Environment, 17(1), 69-79. https://doi.org/10.1177/1420326X07086945

Nguyen, P.D. (2002). Report on research project ,Building databank for architectural design in tropical climate" [unpublished].

Nguyen, A.T., Singh, M.K. \& Reiter, S. (2012). An adaptive thermal comfort model for hot humid south-east Asia. Building and Environ- 
ment, 56, 291-300. https://doi.org/10.1016/ j.buildenv.2012.03.021

Nguyen, N.T.Q. \& Tran, T.C. (2017). Assessing the thermal comfort in non-air conditioned classrooms in Ho Chi Minh City. Science and Technology Development Journal - Natural Sciences, 1(T4), 232-240. https://doi. org/10.32508/stdjns.v1iT4.473

Phong, D.N., Uyen, L.T., Lanh, N.N., Anh, N.H. (1984). Impacts of hot and humid climate on youths in residential buildings, physio-biologically considered. In Proceedings of Vietnam-Sweden Symposium: Vietnam Building Climatology. Hanoi (pp. C32-C43) [unpublished].

Simons, B., Koranteng, C., Adinyira, E. \& Ayarkwa, J. (2014). An assessment of thermal comfort in multi storey office buildings in Ghana. Journal of Building Construction and Planning Research, 2(1), 30-38. https:// doi.org/10.4236/jbcpr.2014.21003

Standartinform (1996). Zdaniya zhilyye $i$ obshchestvennyye. Parametry mikroklimata $v$ pomeshcheniyakh [Residential and public buildings. Microclimate parameters for indoor enclosures] (GOST 30494-1996). Moskva: FHUP Standartinform [transl. from Russian].

Szabo, J. \& Kajtar, L. (2018). Thermal comfort analysis in office buildings with different air-conditioning systems. International Review of Applied Sciences and Engineering, 9(1), 59-63. https://doi.org/10.1556/1848.2018.9.1.8

Szokolay, S.V. (2004). Introduction to architectural science: the basis of sustainable design. Oxford: Architectural Press.

Tao, P., Li, A., Qiu, G. \& Zhang, J. (2014). Field measurement, survey and evaluation on indoor thermal environments in typical office buildings. In A. Li, Y. Zhu, Y. Li (eds.), Proceedings of the 8th International Symposium on Heating, Ventilation and Air Conditioning (pp. 77-86). Berlin: Springer.

Tartarini, F., Schiavon, S., Cheung, T. \& Hoyt, T. (2020). CBE Thermal Comfort Tool: online tool for thermal comfort calculations and visualizations. SoftwareX 12, 100563. https://doi.org/10.1016/j.softx.2020.100563

Thiem, T.H. (1984). The comfortable microclimate parameters in hot humid conditions. In Proceedings of Vietnam-Sweden Symposium:
Vietnam Building Climatology. Hanoi (pp. C21-C26) [unpublished].

Tuan, N.A, Dung, L.T.K. \& Vinh, P.T. (2016). Assessment the indoor environmental quality in low-income apartments in Danang in the summer. Journal of Architectural and Building Sciences, 23, 20-24.

Tuan, N.A. \& Le, T.K. (2015). Thermal comfort in some naturally-ventilated lecture halls. Journal of Science and Technology-Danang University, 1, 84-88.

\section{Summary}

Simple method to improve the TCXDVN 306:2004 indoor climate standard for closed office workplaces in Vietnam. Thermal comfort is an important parameter of indoor climate, which affects office worker health and productivity, and also aids planning for energy efficient building design and operation. To provide satisfactory thermal comfort in office workplaces under hot and humid outdoor conditions, most contemporary office buildings in Vietnam are fitted with ducted air-conditioning systems. The current Vietnamese standard TCXDVN 306:2004 for indoor climate was derived from thermal comfort research conducted between the 1960s and 1980s. This standard is limited by various drawbacks, including no distinction between natural or artificial environments. In response, this 2018 research provides physical measurements and opinion surveys of current indoor climatic conditions in representative office workplaces in three regions of Vietnam: North, Central and South. The measurement results have been transformed into ET, $P M V$ and $P P D$ indicators, which value demonstrate the shortcomings of the TCXDVN 306:2004 standard, while providing a baseline input for updating this standard to meet the thermal comfort needs of air-conditioned office workplaces, based on the concept of probability comfort, which are integral with the ISO and the ASHRAE standard. 


\section{Authors' address:}

Pham Thi Hai Ha

(https://orcid.org/0000-0002-7277-7674)

National University of Civil Engineering

55 Giai Phong road, Hai Ba Trung District

Hanoi

Vietnam

e-mail: hapth@nuce.edu.vn 